\title{
Pengaruh Sistem Akuntansi Manajemen Terhadap Kinerja Manajerial Dengan Strategi Bisnis Sebagai Variabel Pemoderasi
}

\author{
Rizki Fitri Amalia \\ Politeknik Palcomtech, Palembang, Indonesia \\ rizki_fitri@palcomtech.ac.id
}

*Corresponding Author

Diajukan :21 Desember 2021

Disetujui : 26 Desember 2021

Dipublikasi : 1 Januari 2022

\begin{abstract}
This study aims to determine the effect of the management accounting system on managerial performance with business strategy as a moderating variable. The type of research in this study is causal associative. The population in this study is a hotel in the city of Palembang. The sample selected is 3 to 5 star hotels. The sample technique used in this study is purposive sampling and the samples used in this study were 63 samples. Hypothesis testing was carried out using the moderation regression analysis method with the help of SPSS ver 26. The results obtained showed that business strategy was not able to strengthen the relationship between management accounting systems and managerial performance.
\end{abstract}

Keywords: Management Accounting System, Business Strategy, Managerial Performance

\section{PENDAHULUAN}

Menurut Hansen dan Mowen (2016), sistem akuntansi manajemen itu sendiri merupakan proses mengidentifikasi, mengumpulkan, mengukur, mengklasifikasi dan melaporkan informasi yang bermanfaat bagi pengguna internal dalam merencanakan, mengendalikan dan mengambil keputusan. Dengan adanya sistem akuntansi manajemen mempermudah manajer dalam mengambil keputusan sehingga dapat mencapai tujuan perusahaan. Terdapat empat karakteristik informasi sistem akuntansi manajemen yang berpengaruh dalam pengambilan keputusan yaitu : broadscope (lingkup luas), timeliness (tepat waktu), aggregation (agregat), dan intergration (integrasi). Sistem akuntansi manajemen mempunyai tiga tujuan umum yaitu menyediakan informasi yang dipergunakan dalam perhitungan harga pokok jasa, produk dan tujuan lain yang diinginkan manajemen kemudian menyediakan informasi yang dipergunakan dalam perencanaan, pengendalian, pengevaluasian dan perbaikan berkelanjutan. Dengan adanya ketiga tujuan tersebut dapat diketahui bahwa informasi akuntansi manajemen dapat membantu manajer dalam mengidentifikasi dan menyelesaikan masalah, serta mengevaluasi kinerja.

Dalam hubungan antara Sistem Akuntansi Manajemen dan Kinerja Manajerial, Ernawati (2005) menjelaskan bahwa dukungan output informasi dari sistem sangat diperlukan manajer dalam menjalankan aktivitasnya. Desain sistem akuntansi manajemen berguna untuk membantu organisasi melalui manajer dalam menghasilkan informasi keuangan dan non keuangan untuk kepentingan manajemen atau pihak internal perusahaan untuk mencapai tujuan perusahaan bahkan untuk mengidentifikasi, mengukur dan melaporkan informasi keuangan dalam bentuk laporan keuangan yang sistematis, transparan dan detail yang dapat berguna untuk mengambil keputusan dalam menghadapi masalah-masalah yang ada serta untuk memprediksi dimasa mendatang.

Pada dasarnya pengaruh sistem akuntansi manajemen akan menjadi lebih baik terhadap kinerja manajerial apabila dibarengi dengan strategi bisnis. Menurut Tamalee et al (2008), strategi korporat dan strategi bisnis merupakan elemen penting dalam menghadapi perubahan lingkungan 
Owner: Riset \& Jurnal Akuntansi

e-ISSN : 2548-9224 | p-ISSN : 2548-7507

Volume 6 Nomor 1, Januari 2021

DOI : https://doi.org/10.33395/owner.v6i1.604.

sebagai upaya untuk mencapai tujuan perusahaan. Perusahaan dalam mempertahankan keberadaannya di tengah persaingan bisnis yang ketat akan memilih dan menerapkan strategi yang fit dengan karakter perusahaannya. Perusahaan yang memilih strategi yang tepat akan mampu bertahan dalam keberlangsungan perusahaan kemudian strategi bisnis yang tepat dapat meningkatkan kinerja manajerial apabila diterapkan dengan benar dan dengan adanya strategi bisnis perusahaan mampu menentukan arah perusahaan menjadi yang lebih baik.

Pada dasarnya penelitian ini sudah ada seperti yang dilakukan oleh Wibowo dan Hariyati (2018) mengenai pengaruh strategi bisnis prospector terhadap kinerja keuangan yang di mediasi oleh sistem informasi akuntansi manajemen pada perusahaan jasa perhotelan di Surabaya. Hasil penelitian menyatakan bahwa strategi prospector berpengaruh positif dan signifikan terhadap kinerja keuangan. Penelitian yang dilakukan oleh Meirianto (2019) mengenai strategi bisnis terhadap kinerja perusahaan dengan manajemen laba sebagai variabel intervening memperoleh hasil bahwa strategi bisnis berpengaruh terhadap kinerja perusahaan karena strategi ini menciptakan keunggulan bersaing. Adapun penelitian yang bertolak belakang dengan hasil di atas yang dilakukan oleh Melasari (2018) tentang pengaruh sistem akuntansi manajemen terhadap kinerja manajerial dengan strategi bisnis sebagai variabel moderasi menunjukkan hasil sistem akuntansi manajemen secara parsial tidak berpengaruh terhadap kinerja manajerial karena strategi bisnis yang diterapkan tidak berjalan secara efektif dan penelitian yang dilakukan Paylosa (2014) mengenai pengaruh strategi bisnis dan desentralisasi terhadap hubungan antara pemanfaatan informasi sistem akuntansi manajemen terhadap kinerja manajerial memperoleh hasil strategi yang mengarah pada prospectors tidak dapat memperkuat hubungan pemanfaatan informasi sistem akuntansi manajemen terhadap kinerja manajerial.

Dengan adanya hasil penelitian yang bertolak belakang maka peneliti tertarik untuk meneliti kembali dengan mengambil judul penelitian "Pengaruh Sistem Akuntansi Manajemen Terhadap Kinerja Manajerial Dengan Strategi Bisnis Sebagai Variabel Pemoderasi."

\section{Teori Kontingensi}

\section{STUDI LITERATUR}

Teori Kontingensi memusatkan perhatiannya pada hukum situasi (Low of The Situation). Menurut pandangan teori kontingensi menjelaskan bahwa pemimpin bisa efektif bilamana ada kesesuaian antara gaya pemimpin dengan sistuasi tertentu (Robbins \& Judge, 2015). Teori kontingensi beranggapan bahwa kepemimpinan itu adalah sebuah proses ketika ingin menjalankan sebuah pengaruhnya sangat berkaitan dengan keadaan dimensi tugas yang dikerjakan oleh suatu kelompok. Menurut Hery (2018), dalam situasi yang berbeda maka gaya kepemimpinan yang akan diterapkan juga akan berbeda.

Pendekatan ini bertujuan untuk mengetahui bahwa ada faktor atau variabel kondisional yang diperkirakan mempengaruhi hubungan sistem akuntansi manajemen dengan kinerja manajerial. Salah satu yang menjadi variabel kondisional adalah variabel pemoderasi. Menurut Sugiyono (2016), variabel pemoderasi adalah variabel yang mempengaruhi (memperkuat atau memperlemah) hubungan antara variabel independen dengan variabel dependen. Dengan adanya variabel pemoderasi dinilai memiliki peran penting dalam mengoptimalkan kinerja manajerial di suatu perusahaan.

Dalam penelitian ini yang bertindak sebagai variabel bebas (independent variable) adalah sistem akuntansi manajemen $(\mathrm{X})$, dan variabel terikat (dependent variable) adalah kinerja manajerial $(\mathrm{Y})$ dengan variabel pemoderasi yakni strategi bisnis $(\mathrm{Z})$.

\section{Strategi Bisnis}

Menurut Mulyono (2012) strategi bisnsi adalah arah atau jalan yang akan ditempuh suatu organisasi dalam rangka menjalankan misi bisnis guna mencapai visi bisnisnya. Pentingnya untuk membuat strategi bisnis yaitu untuk mengetahui kelemahan dan kelebihan perusahaan dengan perusahaan pesaing dan untuk mencapai kesuksesan perusahaan. Menurut Ulya (2020) dan Riyadi, Mahkota, \& Suyadi (2014), Strategi bisnis yang tepat untuk memasarkan produk di masa pandemi covid-19 ini adalah melalui media elektronik dimana antara produsen dan konsumen tidak hertemu langsung pada satw tempat tetapi memiliki jangkauan 
Owner: Riset \& Jurnal Akuntansi

e-ISSN : 2548-9224 | p-ISSN : 2548-7507

Volume 6 Nomor 1, Januari 2021

DOI : https://doi.org/10.33395/owner.v6i1.604.

pemasaran yang sangat luas.

Penelitian ini menggunakan strategi prospector yang mengedepankan inovasi untuk mencapai keunggulan kompetitif. Dimana strategi ini merupakan kebalikan dari strategi defender. Perusahaan yang tergolong dalam tipe strategi prospector adalah perusahaan yang secara terusmenerus mencari peluang pasar baru dengan berkompetisi melalui produk baru dan market development serta bereksperimen dengan melakukan respon-respon potensial terhadap kecenderungan lingkungan yang timbul, sehingga kompetitornya harus senantiasa merespon.

\section{Kinerja Manajerial}

Menurut Rudianto (2015) kinerja manajerial merupakan kemampuan para manajer untuk mengelola seluruh sumber daya yang dimiliki perusahaan dalam rangka memperoleh laba usaha dalam jangka pendek dan jangka panjang. Menurut Robbins dan Coulter (2014) adapun indikator yang dapat mempengaruhi kinerja manajerial adalah sebagai berikut:

1. Kemampuan perencanaan yaitu kemampuan manajemen yang mencakup proses menentukan tugas apa yang harus dilakukan, siapa yang harus melakukan, bagaimana cara mengelompokkan tugas-tugas itu, siapa yang harus melapor ke siapa, dan dimana keputusan harus dibuat.

2. Kemampuan pengorganisasian yaitu kemampuan manajemen yang mencakup proses memotivasi bawahan, mempengaruhi individu atau tim sewaktu mereka bekerja, memiliki saluran komunikasi yang paling efektif, dan memecahkan dengan berbagai cara masalah perilaku karyawan.

3. Kemampuan kepemimpinan yaitu kemampuan manajemen yang mencakup proses pemantauan kinerja aktual, membandingkan actual dengan standar, dan membuat koreksinya jika perlu.

4. Kemampuan pengendalian yaitu kemampuan manajemen yang mencakup proses mendefinisikan sasaran, menetapkan strategi untuk mencapai sasaran dan menyusun rencana untuk mengintegrasikan dan mengkoordinasikan sejumlah kegiatan

\section{Hipotesis}

Menurut teori kontengensi dikatakan bahwa sistem akuntansi manajemen didasarkan pada premis bahwa tidak ada sistem akuntansi manajemen secara universal yang selalu bisa diterapkan dengan tepat pada semua organisasi dalam setiap keadaan maupun saat pengambilan keputusan. Dengan adanya strategi bisnis yang tepat maka diharapkan pengaruh sistem akuntansi manajemen terhadap kinerja manajerial akan semakin kuat

\section{H1: Strategi Bisnis Mampu Memperkuat Hubungan Antara Sistem Akuntansi Manajemen Terhadap Kinerja Manajerial}

\section{Populasi}

\section{METODE}

Menurut Sugiyono (2016), Populasi adalah wilayah generalisasi yang terdiri atas objek atau subjek yang mempunyai kualitas dan karakteristik tertentu yang ditetapkan oleh peneliti untuk dipelajari dan kemudian ditarik kesimpulannya. Berdasarkan hal tersebut, maka populasi dalam penelitian ini seluruh manajer yang bekerja di hotel di Kota Palembang. Ada 24 jumlah hotel yang terdaftar pada $w e b$ traveloka.com.

\section{Sampel}

Teknik pengambilan sampel pada penelitian ini menggunakan metode purposive sampling. Menurut Morissan (2012), pursposive sampling adalah sampel terpilih atau Purposive sampling yang mencakup responden, subjek atau elemen yang dipilih karena karakteristik atau kualitas tertentu, dan mengabaikan mereka yang tidak memenuhi kriteria yang ditentukan. Adapun kriteria pemilihan sampel dalam penelitian ini adalah:

1. Sampel yang dipilih hanya hotel berbintang 3 sampai 5 di Kota Palembang. Hal ini disebabkan karena hotel yang berbintang 3 sampai 5 telah memiliki struktur organisasi yang 
Owner: Riset \& Jurnal Akuntansi

e-ISSN : 2548-9224 | p-ISSN : 2548-7507

Volume 6 Nomor 1, Januari 2021

DOI : https://doi.org/10.33395/owner.v6i1.604.

jelas dimana jika hotel yang berbintang 1 dan 2 belum memiliki struktur organisasi yang jelas.

2. Manajer hotel yang memiliki masa kerja minimal 1 tahun atau lebih dalam hotel tersebut. Hal ini disebabkan karena para manajer tersebut telah memiliki pengalaman dalam tanggung-jawabnya.

Menurut Mahmud (2011), penelitian yang menggunakan analisis data statistik, ukuran sampel paling minimum adalah 30. Maka, berdasarkan teori tersebut sampel yang menjadi acuhan oleh peneliti sebanyak 63 responden yang bekerja sebagai manager hotel.

\section{Teknik Pengumpulan Data}

Teknik pengumpulan data dalam penelitian ini menggunakan teknik angket (kuesioner). Menurut Jogiyanto (2011), teknik pengumpulan data yang dilakukan dengan cara memberi seperangkat pertanyaan kepada responden untuk dijawabnya. Jenis kuesioner yang dipakai adalah kuesioner tertutup dimana dalam kuesioner ini, jawaban sudah disediakan oleh peneliti sehingga responden tinggal memilih saja mana jawaban yang sesuai dengan kebutuhan dalam riset. Peneliti mengambil hasil kuesioner secara online melalui google form. Alasan dilakukan secara online karena penyebaran kuesioner secara langsung tidak memungkinkan untuk dilakukan saat ini mengingat Kota Palembang terkena penyebaran covid-19

\section{Teknik Analisis Data}

Alat analisis data yang digunakan dalam penelitian ini adalah regresi moderasi. Analisis regresi moderasi digunakan untuk menguji peran moderasi dalam hubungannya dengan variabel independen dan dependen. Dirumuskan sebagai berikut:

$\mathrm{KM}=\alpha+\beta_{1} \mathrm{SAM}+\beta_{2} \mathrm{SB}+\beta_{3} \mathrm{SAM} * \mathrm{SB}+\mathrm{e}$

Keterangan:

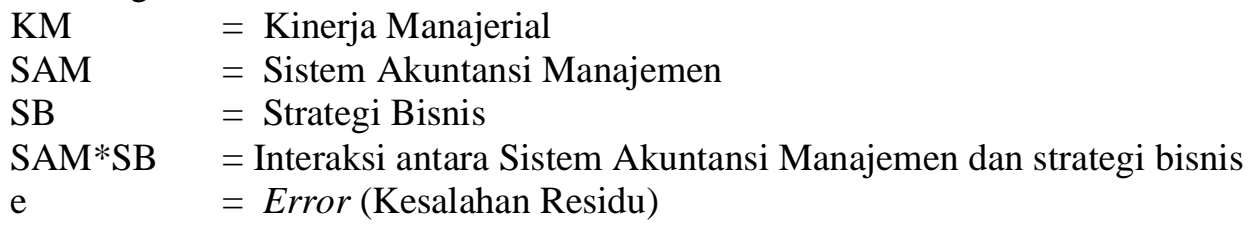

\section{Data Penelitian}

HASIL

Data penelitian diperoleh dengan menggunakan kuesioner online karena keterbatasan kondisi pada saat ini. Penyebaran kuesioner dimulai dari tanggal 03 Mei 2021 hingga 27 Mei 2021 terhadap 24 hotel yang terdaftar pada web traveloka.com dan dilakukan kepada manajer hotel berbintang tiga sampai lima di Kota Palembang yang memenuhi kriteria.

Tabel 1

Hasil Pengumpulan Sampel

\begin{tabular}{lc}
\hline \multicolumn{1}{c}{ Keterangan } & Jumlah Sampel Responden \\
\hline Jumlah kuesioner yang terkumpul & 98 \\
\hline Jumlah kuesioner yang ditolak & 35 \\
\hline $\begin{array}{l}\text { Jumlah kuesioner yang tidak memenuhi } \\
\text { kriteria }\end{array}$ & 0 \\
\hline Jumlah kuesioner yang dapat diolah & 63 \\
\hline Sumber: data primer yang diolah, 2021 &
\end{tabular}

\section{Demografi Responden}

Hasil rekapitulasi profil responden dapat dilihat pada tabel berikut:

\section{Tabel 2}


Owner: Riset \& Jurnal Akuntansi

e-ISSN : 2548-9224 | p-ISSN : 2548-7507

Volume 6 Nomor 1, Januari 2021

DOI : https://doi.org/10.33395/owner.v6i1.604.

Demografi Responden

\begin{tabular}{|c|c|c|}
\hline Keterangan & Jumlah & Persentase \\
\hline \multicolumn{3}{|l|}{ Jenis Kelamin } \\
\hline a. Laki-Laki & 36 & $57,1 \%$ \\
\hline \multirow[t]{2}{*}{ b. Perempuan } & 27 & $42,9 \%$ \\
\hline & 63 & $100 \%$ \\
\hline \multicolumn{3}{|l|}{ Umur } \\
\hline a. 20-30 Tahun & 6 & $9,5 \%$ \\
\hline b. 31-40 Tahun & 41 & $65,1 \%$ \\
\hline \multirow[t]{2}{*}{ c. $>40$ Tahun } & 16 & $25,4 \%$ \\
\hline & 63 & $100 \%$ \\
\hline \multicolumn{3}{|l|}{ Jabatan } \\
\hline a. Manajer Lain lain & 23 & $36,5 \%$ \\
\hline b. Manajer SDM & 18 & $28,6 \%$ \\
\hline c. Manajer Keuangan & 8 & $12,7 \%$ \\
\hline d. Manajer Pemasaran & 6 & $9,5 \%$ \\
\hline \multirow[t]{2}{*}{ e. Manajer Operasional } & 8 & $12,7 \%$ \\
\hline & 63 & $100 \%$ \\
\hline \multicolumn{3}{|l|}{ Lama Bekerja } \\
\hline a. $<1$ Tahun & - & - \\
\hline b. 1-3 Tahun & 20 & $31,7 \%$ \\
\hline c. 3-5 Tahun & 28 & $44,4 \%$ \\
\hline \multirow[t]{2}{*}{ d. > 5 Tahun } & 15 & $23,9 \%$ \\
\hline & 63 & $100 \%$ \\
\hline \multicolumn{3}{|l|}{ Pendidikan Terakhir } \\
\hline a. $\mathrm{S} 2$ & 4 & $6,3 \%$ \\
\hline b. S1 & 38 & $60,3 \%$ \\
\hline c. Diploma & 19 & $30,2 \%$ \\
\hline \multirow[t]{2}{*}{ d. Lain-lain } & 2 & $3,2 \%$ \\
\hline & 63 & $100 \%$ \\
\hline
\end{tabular}

Sumber: data primer yang diolah, 2021

Berdasarkan dari hasil tabel 2 di atas, maka dapat dilihat bahwa mayoritas umur manajer level menengah hotel berbintang tiga sampai dengan lima di Kota Palembang didominasi pada rentang umur 31 sampai dengan 40 tahun, sebesar $65,1 \%$ dari jumlah sampel penelitian ini. Jenis kelamin manajer hotel di kota Palembang, rata-rata didominasi oleh laki-laki, sebesar 57,1\% dari jumlah sampel penelitian ini. Terkait dengan jabatan, mayoritas responden menjawab dengan lainnya sebesar 36,5\% dimana contohnya adalah manajer engineering manager, CO manager, coordinator manager, food and beverage manager, serta front office manager. Untuk lama bekerja didominasi dari 3-5 tahun, sebesar 44,4\%. Dilihat dari pendidikan terakhir, didominasi dengan lulusan $\mathrm{S} 1$ sebanyak 60,3\%.

\section{Statistik Deskriptif}

Tabel 3

Hasil Uji Statistik Deskriptif

\begin{tabular}{cccccc}
\hline Variabel & N & Min & Max & Mean & $\begin{array}{c}\text { Standar } \\
\text { Deviasi }\end{array}$ \\
\hline SAM & 63 & 46 & 65 & 57,07 & 4,91312 \\
\hline KM & 63 & 29 & 40 & 36,04 & 3,10270 \\
\hline
\end{tabular}


Owner: Riset \& Jurnal Akuntansi

e-ISSN : 2548-9224 | p-ISSN : 2548-7507

Volume 6 Nomor 1, Januari 2021

DOI : https://doi.org/10.33395/owner.v6i1.604.

\begin{tabular}{cccccc}
\hline SB & 63 & 35 & 50 & 44,76 & 3,62213 \\
\hline Valid N & 63 & & & & \\
\hline Sumber: data primer yang diolah, 2021
\end{tabular}

Berdasarkan Tabel 3 di atas, hasil statistik deskriptif menunjukkan bahwa variabel Sistem Akutansi Manajemen (X) memiliki nilai minimum sebesar 46 dan nilai maksimum sebesar 65 dengan nilai rata-rata sebesar 57,07 dan dengan standar deviasi sebesar 4,91312 yang berarti bahwa pengukuran instrumen untuk variabel sistem akuntansi manajemen mendekati skala 5 (sangat setuju) sehingga dapat dikatakan bahwa mereka telah menerapkan sistem akuntansi manajemen pada perhotelan mereka. Sedangkan, variabel kinerja manajerial (Y) memiliki nilai minimum sebesar 29 dan nilai maksimum sebesar 40 dengan nilai rata-rata 36,04 dan standar deviasi sebesar 3,10270 sehingga dapat dikatakan bahwa kinerja manajerial pada perhotelan telah diterapkan. Kemudian variabel strategi bisnis (Z) memiliki nilai minimum sebesar 35 dan nilai maksimum sebesar 50 dengan nilai rata-rata 44,76 dan standar deviasi sebesar 3,62213 dapat dikatakan instrumen untuk variabel strategi bisnis mendekati skala 4 dengan demikian perhotelan yang ada hampir dapat menerapkan strategi bisnis yang ada.

\section{Uji Kualitas Instrumen}

Uji Validitas

Tabel 4

Hasil Uji Validitas

\begin{tabular}{llll}
\hline $\begin{array}{c}\text { Butir } \\
\text { Pertanyaan }\end{array}$ & Output SPSS ('rhitung) & r tabel & Ket \\
\hline \multicolumn{1}{l}{ Sistem Akuntansi Manajemen (X) } & 0,506 & 0,2441 & Valid \\
\hline Butir 1 & 0,619 & 0,2441 & Valid \\
\hline Butir 2 & 0,602 & 0,2441 & Valid \\
\hline Butir 3 & 0,569 & 0,2441 & Valid \\
\hline Butir 4 & 0,738 & 0,2441 & Valid \\
\hline Butir 5 & 0,674 & 0,2441 & Valid \\
\hline Butir 6 & 0,393 & 0,2441 & Valid \\
\hline Butir 7 & 0,440 & 0,2441 & Valid \\
\hline Butir 8 & 0,497 & 0,2441 & Valid \\
\hline Butir 9 & 0,567 & 0,2441 & Valid \\
\hline Butir 10 & 0,488 & 0,2441 & Valid \\
\hline Butir 11 & 0,447 & 0,2441 & Valid \\
\hline Butir 12 & 0,578 & 0,2441 & Valid \\
\hline Butir 13 & & & \\
\hline Kinerja Manajerial (Y) & 0,713 & 0,2441 & Valid \\
\hline Butir 1 & 0,2441 & Valid \\
\hline Butir 2 & 0,2441 & Valid \\
\hline Butir 3 & 0,521 & Valid \\
\hline Butir 4 & 0,601 & 0,2441 & Valid \\
\hline Butir 5 & 0,597 & 0,2441 & Valid \\
\hline Butir 6 & 0,557 & 0,2441 & Valid \\
\hline Butir 7 & 0,2441 & Valid \\
\hline Butir 8 & 0,614 & 0,2441 & Valid \\
\hline Strategi Bisnis (Z) & 0,376 & & \\
\hline Butir 1 & 0,660 & 0,2441 & \\
\hline Butir 2 & 0,561 & & \\
\hline Butir 3 & 0,456 & & \\
\hline
\end{tabular}

This is an Creative Commons License This work is licensed under a Creative Commons Attribution-NonCommercial 4.0 International License. 
Owner: Riset \& Jurnal Akuntansi

e-ISSN : 2548-9224 | p-ISSN : 2548-7507

Volume 6 Nomor 1, Januari 2021

DOI : https://doi.org/10.33395/owner.v6i1.604.

\begin{tabular}{llll}
\hline Butir 4 & 0,621 & 0,2441 & Valid \\
\hline Butir 5 & 0,498 & 0,2441 & Valid \\
\hline Butir 6 & 0,693 & 0,2441 & Valid \\
\hline Butir 7 & 0,536 & 0,2441 & Valid \\
\hline Butir 8 & 0,663 & 0,2441 & Valid \\
\hline Butir 9 & 0,581 & 0,2441 & Valid \\
\hline Butir 10 & 0,616 & 0,2441 & Valid \\
\hline
\end{tabular}

Sumber : data primer yang diolah, 2021

Berdasarkan tabel 4 diatas maka dapat dikatakan bahwa, semua butir pertanyaan dari variabel penelitian valid karena memiliki nilai $\mathrm{R}$ Hitung > nilai $\mathrm{R}$ tabel.

\section{Uji Reliabilitas}

Tabel 5

Hasil Uji Reliabilitas

\begin{tabular}{cccc}
\hline Variabel & Cronbatch's Alpha & Cronbach Alpha & Ket \\
\hline $\begin{array}{c}\text { Sistem Akuntansi } \\
\text { Manajemen (X) }\end{array}$ & 0,801 & 0,70 & Reliabel \\
\hline $\begin{array}{c}\text { Kinerja Manajerial } \\
\text { (Y) }\end{array}$ & 0,707 & 0,70 & Reliabel \\
\hline Strategi Bisnis (Z) & 0,762 & 0,70 & Reliabel \\
\hline Sumber: data primer yang diolah, 2021 & &
\end{tabular}

Berdasarkan pengujian reliabilitas pada Tabel 5 di atas diketahui bahwa hasil pengujian reliabilitas atas pernyataan, seluruh variabel menunjukkan nilai Cronbach's Alpha $>0,70$. Dengan demikian dapat dinyatakan bahwa variabel yang digunakan dalam kuesioner pada penelitian ini dinyatakan reliabel.

\section{Uji Normalitas}

\section{Tabel 6}

Hasil Uji Normalitas

\begin{tabular}{cc}
\hline Keterangan & Unstandardized Residual \\
\hline Asymp.Sig. (2-tailed) & 0,200 \\
\hline Sumber: data primer yang diolah, 2021
\end{tabular}

Pengujian normalitas residual dilakukan menggunakan teknik Kolmogorov-Smirnov. Jika nilai sig $>0,05$ maka data berdistribusi normal dan sebaliknya. Pada Tabel 6 data menunjukkan bahwa nilai signifikasinya sebesar $0,200>0,05$. Hal ini menunjukkan bahwa data memenuhi syarat untuk dapat dikatakan normal.

\section{Uji Multikolinearitas}

\section{Tabel 7}

Hasil Uji multikolinearitas

Setelah Bootstrapping

\begin{tabular}{cccc}
\hline Variabel & Sig & VIF & Ket \\
\hline $\mathrm{X}$ & 0,162 & 6,189 & Tidak multikolinearitas \\
\hline $\mathrm{Z}$ & 0,361 & 2,771 & Tidak multikolinearitas \\
\hline $\mathrm{XZ}$ & 0,204 & 4,904 & Tidak multikolinearitas \\
\hline
\end{tabular}

Sumber: data primer yang diolah, 2021

Pengujian multikolinearitas dilakukan oleh peneliti menggunakan program SPSS 26 dengan $\underline{\text { melihat nilai Tolerance dan VIF. Jika nilai Tolerance }<0,10 \text { atau nilai VIF }>10 \text { maka tidak terjadi }}$

This is an Creative Commons License This work is licensed under a Creative Commons Attribution-NonCommercial 4.0 International 
Owner: Riset \& Jurnal Akuntansi

e-ISSN : 2548-9224 | p-ISSN : 2548-7507

Volume 6 Nomor 1, Januari 2021

DOI : https://doi.org/10.33395/owner.v6i1.604.

multikolinearitas. Berdasarkan hasil pengujian multikolinearitas pada tabel 7 disimpulkan bahwa semua variabel bebas multikolinearitas. Peneliti melakukan

Menurut Jogiyanto (2011), pada model moderasi wajar adanya terjadi multikolineritas dikarenakan adanya perkalian antara variabel independen dengan variabel moderasi dalam peregresiannya. Hal serupa juga dinyatakan oleh Ghozali (2019), bahwa model regresi moderasi kerap kali terjadi masalah multikolinearitas dan ini bisa diabaikan. Peneliti menggunakan Metode bootstrap, yaitu metode berbasis resampling data sampel dengan syarat pengembalian pada datanya dalam menyelesaikan statistik ukuran suatu sampel dengan harapan sampel tersebut mewakili data populai sebenarnya.

\section{Uji Heteroskedastisitas}

Tabel 8

Hasil Uji Heteroskedastisitas

\begin{tabular}{ccc}
\hline Variabel & Sig & Keterangan \\
\hline Sistem Akuntansi Manajemen $(\mathrm{X})$ & 0,286 & Tidak terjadi heteroskedastisitas \\
\hline Strategi Bisnis $(\mathrm{Z})$ & 0,487 & Tidak terjadi heteroskedastisitas \\
\hline Sumber: data primer yang diolah, 2021 & &
\end{tabular}

Berdasarkan Tabel 8 di atas menunjukkan bahwa semua variabel mempunyai nilai probabilitas signifikansi lebih besar dari 0,05. Dengan demikian dapat disimpulkan bahwa hasil olah data kuesioner dalam penelitian ini tidak terjadi heteroskedastisitas.

Uji Regresi Moderasi (MRA)

Tabel 9

Hasil Uji Moderated Regression Analysis (MRA)

\begin{tabular}{cccc}
\hline \multirow{2}{*}{ Variabel } & \multicolumn{3}{c}{ Nilai } \\
\cline { 2 - 4 } & Koefisien Regresi & T hitung & Sig \\
\hline Konstanta & $-18,188$ & $-0,469$ & 0,641 \\
\hline $\mathrm{X}$ & 0,556 & 0,790 & 0,433 \\
\hline $\mathrm{Z}$ & 0,992 & 1,163 & 0,249 \\
\hline $\mathrm{XZ}$ & $-0,009$ & $-0,558$ & 0,579 \\
\hline Sumber: data primer yang diolah, 2021 & &
\end{tabular}

Berdasarkan Tabel 9 di atas menunjukkan hasil uji Analisis Regresi Moderasi (MRA), dapat diketahui persamaan regresi hipotesis sebagai berikut:

$\mathrm{KM}=-18,188+0,556 \mathrm{SAM}+0,992 \mathrm{SB}-0,009 \mathrm{SAM} * \mathrm{SB}+\mathrm{e}$

Persamaan di atas menunjukkan nilai konstanta sebesar -18,188 dan mempunyai nilai yang negatif. Nilai tersebut berarti dengan adanya sistem akuntansi manajemen $(X)$, strategi bisnis $(Z)$, dan interaksi antara sistem akuntansi manajemen (X) dengan strategi bisnis (Z) tidak mengalami perubahan, maka kinerja manajerial (Y) akan mengalami penurunan sebesar -18,188. Jika nilai koefisien sistem akuntansi manajemen sebesar 0,556 berarti bila terjadi kenaikan sebesar satu maka kinerja manajerial akan meningkat sebesar 0,556. Kemudian jika nilai koefisien strategi bisnis sebesar 0,992 berarti bila terjadi kenaikan sebesar satu maka kinerja manajerial akan meningkat sebesar 0,992, dan untuk nilai koefisien sistem akuntansi manajemen dengan strategi bisnis sebesar - 0,009 maka berarti bila terjadi kenaikan sebesar satu maka kinerja manajerial akan menurun sebesar -0,009.

\section{Pengujian Hipotesis}

Uji Statistik F

Tabel 10

Hasil Uji F

This is an Creative Commons License This work is licensed under a Creative Commons Attribution-NonCommercial 4.0 International License. 
Owner: Riset \& Jurnal Akuntansi

e-ISSN : 2548-9224 | p-ISSN : 2548-7507

Volume 6 Nomor 1, Januari 2021

DOI : https://doi.org/10.33395/owner.v6i1.604.

\begin{tabular}{ccc}
\hline Model & F & Sig \\
\hline Regression & 27,559 & 0,000 \\
\hline \multicolumn{3}{l}{ Sumber: data primer yang diolah, 2021}
\end{tabular}

Sumber: data primer yang diolah, 2021

Berdasarkan Tabel 10 di atas menunjukkan nilai F sebesar 27,559 dengan tingkat signifikan 0,000 maka dapat disimpulkan bahwa nilai signifikan lebih kecil dari 0,05 sehingga terdapat pengaruh yang signifikan terhadap semua variabel independen terhadap variabel dependen.

\section{Uji Statistik T}

Tabel 11

Hasil Uji T

\begin{tabular}{cccc}
\hline Variabel & T & Sig & Ket \\
\hline XZ & 0,558 & ),579 & Ditolak \\
\hline Sumber: data & primer yang diolah, & 2021
\end{tabular}

Berdasarkan pada Tabel 11 di atas diperoleh hasil pengujian statistik t yang menunjukkan bahwa hasil uji interaksi antara variabel sistem akuntansi manajemen dan strategi bisnis memiliki nilai t hitung sebesar -0,558 dengan tingkat signifikansi 0,579 lebih besar dari 0,05 yang berarti bahwa hipotesis alternatif ditolak yang menunjukkan bahwa dengan adanya variabel strategi bisnis tidak mampu memoderasi hubungan sistem akuntansi manajemen dengan kinerja manajerial.

\section{Uji Koefisien Determinasi $\left(\mathbf{R}^{2}\right)$}

Tabel 12

Hasil Uji Koefisien Determinasi $\left(\mathbf{R}^{2}\right)$

\begin{tabular}{cccc}
\hline Hipotesis & $\mathbf{R}$ & $\begin{array}{c}\mathbf{R} \\
\text { Square }\end{array}$ & Adjusted $\boldsymbol{R}$ Square \\
\hline 1 & 0,764 & 0,584 & 0,562 \\
\hline \multicolumn{4}{l}{ Sumber: data primer yang diolah, 2021}
\end{tabular}

Berdasarkan hasil Tabel 12 di atas nilai koefisien korelasi Adjusted $R$ Square $\left(R^{2}\right)$ sebesar 0,562 . Dapat disimpulkan bahwa sebesar $56,2 \%$ variabel independen $(X)$ dapat menjelaskan variabel dependen (Y). Sedangkan $43,8 \%$ dijelaskan oleh faktor lain yang tidak diteliti dalam penelitian ini. Hal ini dapat menunjukkan bahwa masih terdapat variabel lain yang dapat mempengaruhi sistem akuntansi manajemen.

\section{PEMBAHASAN}

Strategi bisnis tidak mampu memperkuat hubungan antara sistem akuntansi manajemen terhadap kinerja manajerial.

Berdasarkan hasil regresi pada uji $\mathrm{t}$, dapat dilihat bahwa hasil sig moderasi adalah 0,579 di mana sig > 0,05 yang berarti hipotesis ditolak. Hal ini berarti variabel strategi bisnis tidak dapat memoderasi hubungan antara sistem akuntansi manajemen terhadap kinerja manajerial karena tingkat signifikansi lebih besar dari 0,05 . Hasil dari penelitian ini juga tidak sejalan dengan teori kontingensi karena strategi bisnis yang dinilai dapat memiliki peran yang penting untuk mengoptimalkan kinerja manajerial di tengah kondisi persaingan bisnis perhotelan yang lesu nyatanya tidak memberikan pengaruh.

Hal ini menunjukkan bahwa penerapan strategi bisnis yang ada di perhotelan di Kota Palembang belum tepat atau belum terintegrasi dengan baik sehingga tidak memberikan pengaruh terhadap hubungan antara sistem akuntansi manajemen terhadap kinerja manajerial. Hal ini disebabkan karena penerapan strategi bisnis yang ada di perhotelan dengan yang diteliti berbeda dan juga penerapan strategi bisnis belum berjalan secara efektif dan efisien. Dimana dengan adanya strategi bisnis yang efektif dan efisien dapat memberikan kontribusi dalam memberikan hasil keputusan terbaik yang dapat berdampak bagi kelangsungan hidup perusahaan sehingga 
Owner: Riset \& Jurnal Akuntansi

e-ISSN : 2548-9224 | p-ISSN : 2548-7507

Volume 6 Nomor 1, Januari 2021

DOI : https://doi.org/10.33395/owner.v6i1.604.

diharapkan dapat meningkatkan kinerja manajerial pada perhotelan yang ada. Temuan ini sendiri akan menjadi masukan bagi pihak manajemen hotel untuk mencoba mengevaluasi kembali strategi bisnis yang digunakan sehingga ke depannya bisa terintegrasi dengan baik dan berdampak positif dalam memperkuat dampak dari penggunaan sistem akuntansi manajemen terhadap kinerja manajerial.

Hasil penelitian ini sejalan dengan hasil dari penelitian yang dilakukan oleh Melasari (2018) yang menyatakan bahwa sistem akuntansi manajemen secara parsial tidak berpengaruh terhadap kinerja manajerial dengan variabel moderasi strategi bisnis. Hal ini disebabkan oleh strategi bisnis yang diterapkan tidak berjalan secara efektif.. Selain itu, tidak adanya pengaruh sistem akuntansi manajemen terhadap kinerja manajerial dengan strategi bisnis sebagai variabel moderasi juga dapat dikarenakan pemilihan strategi bisnis yang tidak tepat oleh perusahaan.

\section{KESIMPULAN}

Penelitian ini bertujuan untuk mengetahui sistem akuntansi manajemen terhadap kinerja manajerial dengan strategi bisnis sebagai variabel pemoderasi. Berdasarkan pembahasan pada bab sebelumnya, dapat disimpulkan bahwa penerapan strategi bisnis yang ada di perholetan di Kota Palembang belum tepat atau belum terintegrasi dengan baik sehingga tidak memberikan pengaruh terhadap hubungan antara sistem akuntansi manajemen dengan kinerja manajerial. Hal ini disebabkan oleh strategi bisnis yang diterapkan belum berjalan secara efektif dan efisiciptoen.

\section{REFERENSI}

Ernawati. 2005. Pengaruh Strategi Bisnis dan Ketidakpastian Lingkungan Terhadap Hubungan Antara Informasi Broad Scope Sistem Akuntansi Manajemen dan Kinerja Manajerial. Jurnal Akuntansi Dan Investasi, 6, 21-39.

Ghozali,Imam.2019. Aplikasi Analisis Multivariete. Semarang: Universitas Diponegoro.

Hansen dan Mowen. 2015. Akuntansi Manajerial. Edisi 8. Salemba Empat. Jakarta.

Hery. 2018. Pengantar Manajemen. Cetakan Pertama. PT Grasindo. Jakarta

Jogiyanto. 2011. Metodologi Penelitian Bisnis. Edisi Keempat. Yogyakarta: BPFE.

Mahmud. 2011. Metode Penelitian Pendidikan. Bandung: CV Pustaka Setia.

Meirianto, Rico. 2019. Pengaruh Strategi Bisnis Dan Ukuran Perusahaan Terhadap Kinerja Perusahaan Dengan Manajemen Laba Sebagai Variabel Intervening. Thesis. IBII Darmajaya.

Melasari, Ranti. 2018. Pengaruh Sistem Akuntansi Manajemen Terhadap Kinerja Manajerial Dengan Strategi Bisnis Sebagai Variabel Moderasi Pada PT. Pulau Sambu Guntung. Journal of Chemical Information and Modeling, 53(9),1-14.

Morissan M., dkk. 2012. Metode Penelitian Survei. Jakarta: Kencana.

Mulyono, Djoko. 2012. Buku Pintar Strategi Bisnis Koperasi Simpan Pinjam. Andi Offset. Yogyakarta.

Paylosa, F. 2014. Pengaruh Strategi Bisnis dan Desentralisasi Terhadap Hubungan Antara Pemanfaatan Informasi Sistem Akuntansi Manajemen dan Kinerja Manajerial. Jurnal Akuntansi FE Universitas Negeri Padang, Volume 9,6-8.

Riyadi, Mahkota, A. P., \& Suyadi, I. 2014. Pengaruh Kepercayaan dan Kenyamanan Terhadap Keputusan Pembelian. Jurnal Administrasi Bisnis, 8(2), 1-7.

Robbins, Stephen P. and Mary Coulter. 2016. Manajemen, Jilid 1 Edisi 13, Alih Bahasa: Bob Sabran Dan Devri Bardani P, Erlangga, Jakarta.

Rudianto. 2015. Akuntansi manajemen. Yogyakarta;Kalimedia.

Sugiyono. 2016. Metode Penelitian Bisnis. Bandung: Alfabeta.

Tamalee, Kitima, Mohamed Sulaiman, and Ishak Ismail, 2008, Business Strategy and Performance of Manufacturing Firmsin Thailand, Dipresentasikan pada Oxford Business \& Economics Conference Program, Oxford.

Ulya, H. N. 2020. Alternatif Strategi Penanganan Dampak Ekonomi Covid-19 Pemerintah Daerah Jawa Timur Pada Kawasan Agropolitan. el Barka: Journal of Islamic Economic and Business, 3(1), 80- 109.

Wibowo, H. W., \& Hariyanti. 2018. Pengaruh Strategi Bisnis Prospector Terhadap Kinerja 
Owner: Riset \& Jurnal Akuntansi

e-ISSN : 2548-9224 | p-ISSN : 2548-7507

Volume 6 Nomor 1, Januari 2021

DOI : https://doi.org/10.33395/owner.v6i1.604.

Keuangan Yang Di Mediasi Oleh Sistem Informasi Akuntansi Manajemen Pada Perusahaan Jasa Perhotelan Di Surabaya. Jurnal Akuntansi Unesa, 4-7. 